\title{
NOTES ON DICRANUM (DICRANACEAE, MUSCI) IN RUSSIA. 2. DICRANUM PSEUDACUTIFOLIUM SP. NOV., FROM NORTH SIBERIA
}
ЗАМЕТКИ ПО РОДУ DICRANUM (DICRANACEAE, MUSCI) В РОССИИ. 2. DICRANUM PSEUDACUTIFOLIUM SP. NOV. ИЗ СЕВЕРНОЙ СИБИРИ

\author{
T.N. OTNYUKOVA ${ }^{1,2}$ \\ T.Н. ОТНЮКОВА ${ }^{1,2}$
}

Abstract

\begin{abstract}
A new species, Dicranum pseudacutifolium Otnyukova is described from North Siberia, Putorana Plateau. It is similar to $D$. acutifolium and $D$. brevifolium but differs from both species in the absence of bulgings above cell walls as it is seen on transversal leaf section, in not porose lower leaf cells, and in inner perichaetial leaves abruptly contracted into subula. It differs from $D$. flexicaule and $D$. fuscescens in leaf cross section looking like pair of tongs, and from the latter also in relatively scarce rhizoids, and in wide leaf base. A specific feature of this new species is straight cell walls making cell angles sharp, not rounded.
\end{abstract}

Резюме

С плато Путорана (север Сибири) описан новый вид Dicranum pseudacutifolium Otnyukova sp. nov. По характеру дерновинок и форме листа он близок к D. acutifolium и D. brevifolium, но отличается от них отсутствием на поперечном срезе листа выступов клеточных стенок, не пористыми клеточными стенками в нижней части листа и перихециальными листьями резко суженными в узкую верхушку. От D. flexicaule и $D$. fuscescens новый вид отличается формой поперечного среза листа (края изогнуто-сходящиеся как оленьи рога), от последнего - более редкими ризоидами и более широким основанием. Клетки нового вида имеют прямые стенки, так что углы клеток выглядят резкими, не закругленными.

The revision of Dicranum species with quadrate upper cells in KRF, LE, SASY reveals in the north of Krasnoyarsk District (Siberia) D. flexicaule Brid., D. fuscescens Turn., D. acutifolium (Lindb. \& Arn.) C.Jens., D. brevifolium (Lindb.) Lindb., and a new species that is described below.

Dicranum pseudacutifolium Otnyukova sp.nov.

Figs. 1-2

Caespites laxi vel densi, ad $10 \mathrm{~cm}$ alti. Folia valde haud flexuosa, margine superne dentato et ex parte bistrato. Vena superne scabra, apiculus dentatus. Cellulae laminorum superne quadratarae, aut subquadratae, aut brevirectangulares, leptodermaticae, non porosae, papillosae aut ad leves. Cellulae laminorum inferne rectangulatae, leptodermaticae, non porosae aut ad leviter porosae.
Folia tranverse secta carinata. TYPUS: Russia, prov. Krasnojarskensis, planities Putorana, fl. Neralakh, systema lacus Lama, 69 40' lat. bor., 89 50 ' long. orient., $200 \mathrm{~m}$ alt., ad solum. 29.VII.1991. T.N. Otnyukova (holotypus KRF).

Plants in loose or somewhat dense mats, relatively soft and flexible, dark-green to green (sometimes yellow-green only in herbaria) above and dullbrown to dark-brown below, slightly glossy. Stems to $10 \mathrm{~cm}$ high, scarcely to densely foliate, with loose rhizoid tomentum. Leaves somewhat falcate when dry and straight when wet, 5-7 mm long and 0.7$0.9(-1.1) \mathrm{mm}$ wide, from ovate-lanceolate base more or less gradually narrowed to short or long, keeled-channeled subula, at tip acute; margins from strongly bistratose to partially bistratose and from

1 - V. N. Sukachev's Institute for Forest Research, Siberian Branch of Russian Academy of Sciences, Akademgorodok, Krasnoyarsk 660036 Russia - 660036 Красноярск, Академгородок, Институт леса им. В. Н. Сукачева СО РАН

2 - Siberian Federal University, Svobodny Prospect, 79, Krasnoyarsk 660041 Russia - 660041 Красноярск, пр. Свободный 79, Сибирский федеральный Университет 


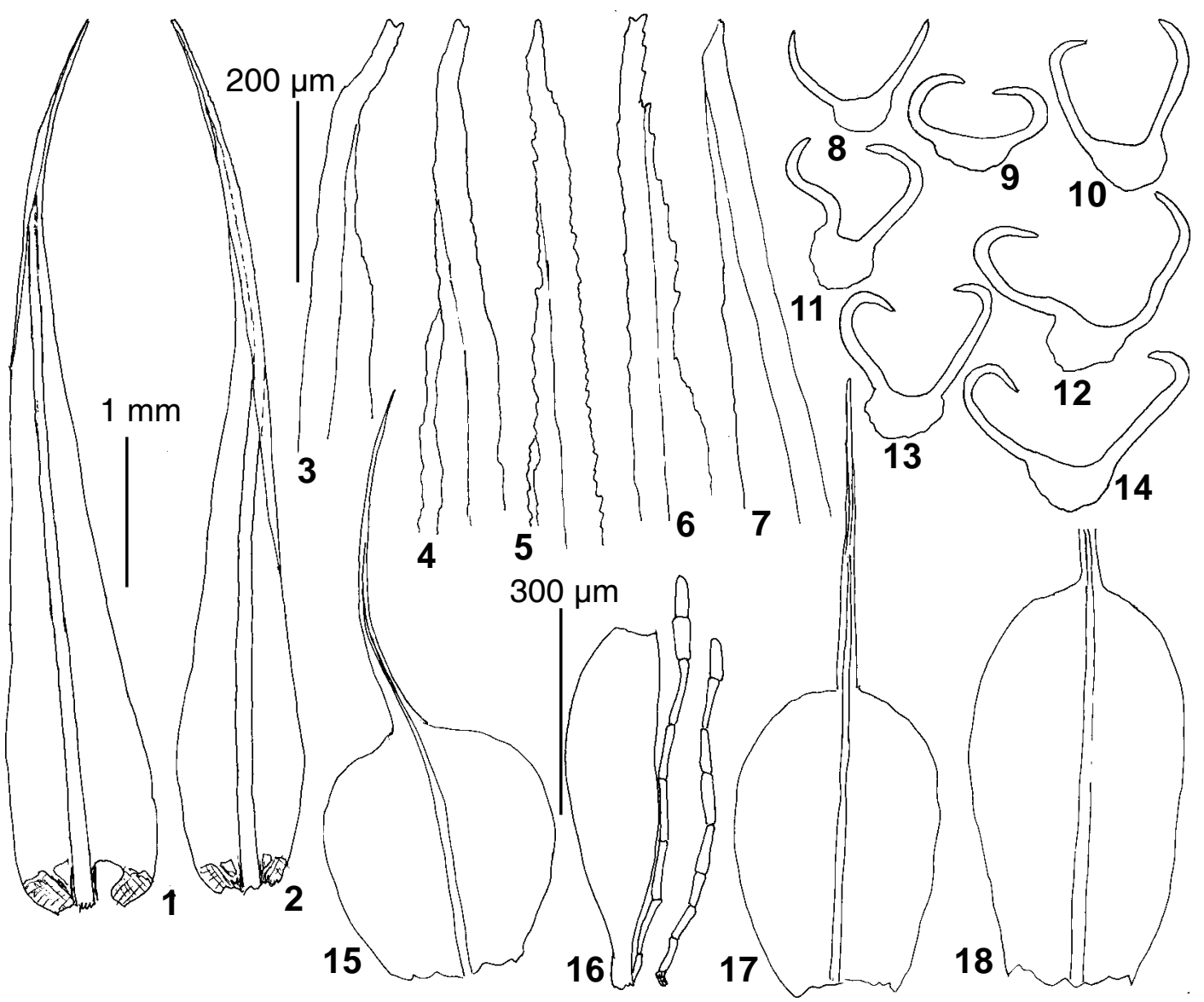

Fig. 1. Dicranum pseudacutifolium Otnyukova sp. nov. (from holotype): 1-2 - leaves; 3-7 - leaf apices; 8-14 - leaf transverse sections; $15,17-18$ - perichaetial leaves; 16 - antheridium with paraphyses. Scale bars: $1 \mathrm{~mm}$ for $1-2 ; 300 \mu \mathrm{m}$ for $15-18 ; 200 \mu \mathrm{m}$ for $3-14$.

strongly serrate to subentire above, always entire below; costa precurrent or shortly excurrent, (1/5-) $1 / 7-1 / 9$ of width of leaf base, from dentate or serrulate to smooth on dorsal surface. Upper leaf cells quadrate, short-rectangular, transverse-rectangular to irregular, (3-)5-10(-25) x 7-9(-12) $\mu \mathrm{m}$, straightwalled, with sharp (not rounded) angles, thin-walled to thick-walled, in cross section cell walls between cells not bulging; lower leaf cells elongate to short elongate, (25-)35-55(-100) x 8-10 $\mu \mathrm{m}$, thin and straight-walled, not pitted (or slightly pitted in old leaves), regular or irregular in shape; often abruptly transiting to short-rectangular and quadrate upper leaf cells; alar cells 2(-3)-stratose, brown; in cross section leaves looking like a pair of tongs, costa with differentiated dorsal epidermis. Dioicous or phyllodioicous. Sporophytes solitary (only green and old sporophytes with destroyed peristome were found). The inner perichaetial leaves concave and not ap- pressed to setae, from obovoid or wide obovoid base abruptly narrowed to cylindrical subula; convolute leaf base 2.5-3.0 mm long, 1.2-1.4 mm wide, subula 2.0-2.5 mm long.

TYPE. Russia, Krasnoyarsk Territory, Putorana Plateau, Neralakh River $10 \mathrm{~km}$ distance from its flow in Lama Lake, 6940’ N, 8950'E, $200 \mathrm{~m}$ elev. Open larch woodland, on skeleton soil. 29.VII.1991. T.N. Otnyukova (holotype KRF, isotype in MHA).

This new species is similar to D. acutifilium and $D$. flexicaule; moreover, these three species grow together in the northern Siberia. Plants of D. pseudacutifolium with sporophytes are easily to recognize by their inner perichaetial leaves that are loosely appressed to setae by concave basal part, while in two other species they are lanceolate, with appressed base. Well-developed vegetative plants of D. pseudacutifolium differ from D. acuti- 


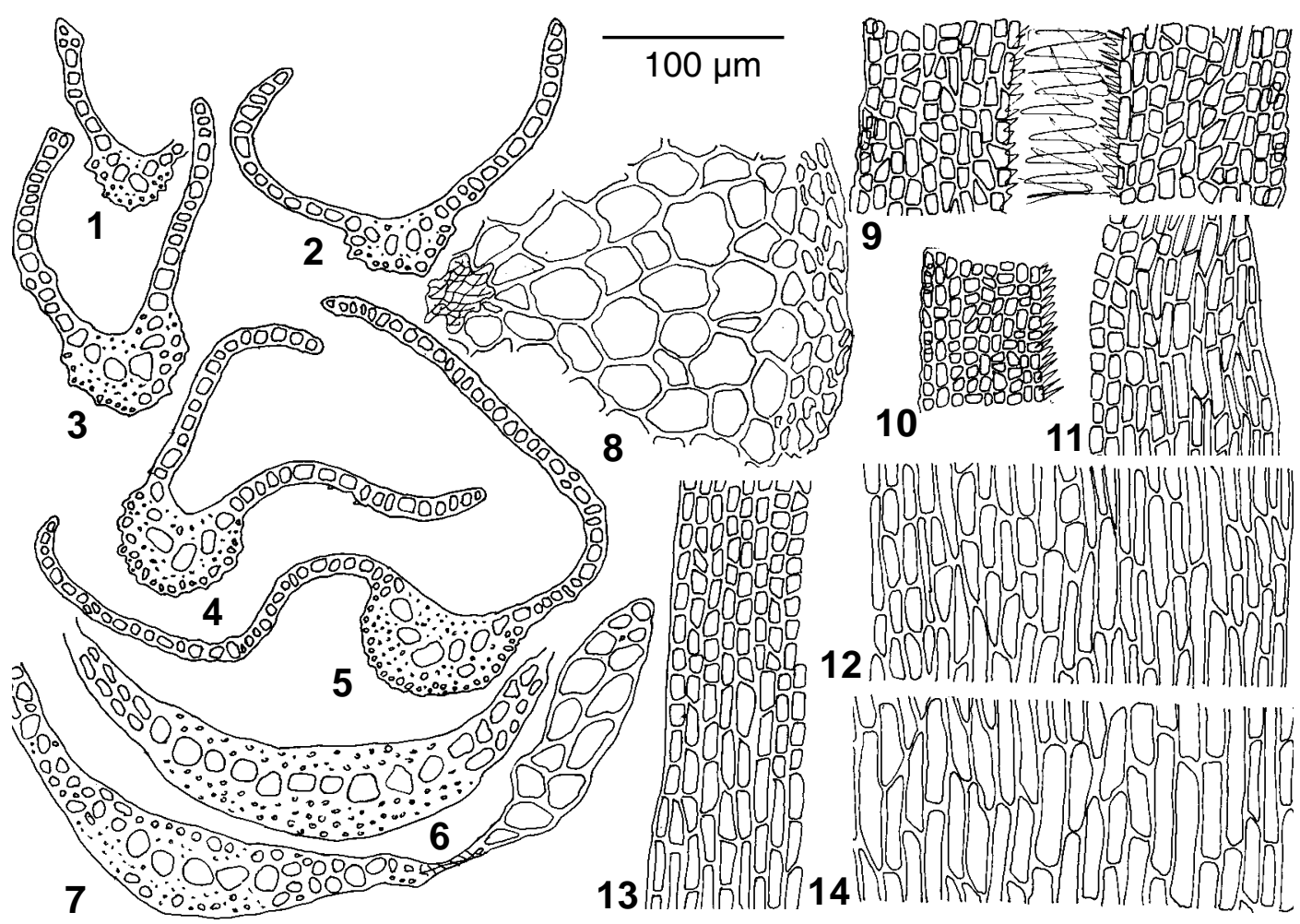

Fig. 2. Dicranum pseudacutifolium Otnyukova sp. nov. (from holotype): 1-7 - leaf transverse sections; 8 - stem transverse section; 9-10 - upper leaf cells; 11 - mid-leaf cells; 12 \& 14 - lower leaf cells; 13 - mid-leaf cells showing abrupt transition from short to elongate cells. Scale bars: $100 \mu \mathrm{m}$ for 1-14.

folium and $D$. flexicaule in its long, wide at base, acuminate leaves that are keeled-channeled, with serrate margins and dorsal costa, as well as in thinwalled lower laminal cells and abrupt transition to small and quadrate upper leaf cells that makes lamina bicolor, with dark upper part and light lower part. This pattern is not conspicous in weakly developed plants that have also only slightly serrulate leaf margin. These weakly developed sterile plants of $D$. pseudacutifolium can be recognized by thin-walled and straight-walled cells, with sharp (not rounded) angles.

The new species differs from $D$. acutifolium primarily in the absence of bulgings above cell walls as it is seen in leaf cross section. Also it usually has not porose, thin-walled leaf cells, with sharp, not rounded angles (vs. always porose, thick-walled cells with rounded angles in D. acutifolium).

The differences from $D$. brevifolium include absence of bulgings in leaf transverse section and not porose lower laminal cells.

Dicranum pseudacutifolium differs from $D$. fuscescens in wider leaf base, up to 30-50 cells wide (vs. 15-25 in D. fuscescens) and also in wider and more thin-walled lower leaf cells, as well as in leaf cross section keeled-channeled, looking like pair of tongs (vs. V-shaped in D. fuscescens).

The new species differs from $D$. flexicaule in thin, straight and not porose laminal cell and in keeled-channeled, looking like pair of tongs leaf cross section (vs. kelled-tubulose in D. flexicaule). The unistratose lamina above is shorter and 3$5(-7)$ cells wide vs. longer and only (1-)2-3(-5) cells wide in $D$. flexicaule.

Comparison of D. pseudacutifolium with similar species is given also in Table 1.

Variation. Dicranum pseudacutifolium is variable in tuft density (loose or dense), plants (more or less tomentose), leaves (straight to rather falcate), upper leaf shape (from longly to shortly acuminate), dorsal surface of costa (serrate to smooth), margin of leaf (serrate to entire), upper leaf cells (much shorter to quadrate and therefore thin-walled to much longer and irregular in shape and then more thick-walled), lower leaf cells ( \pm porose). 


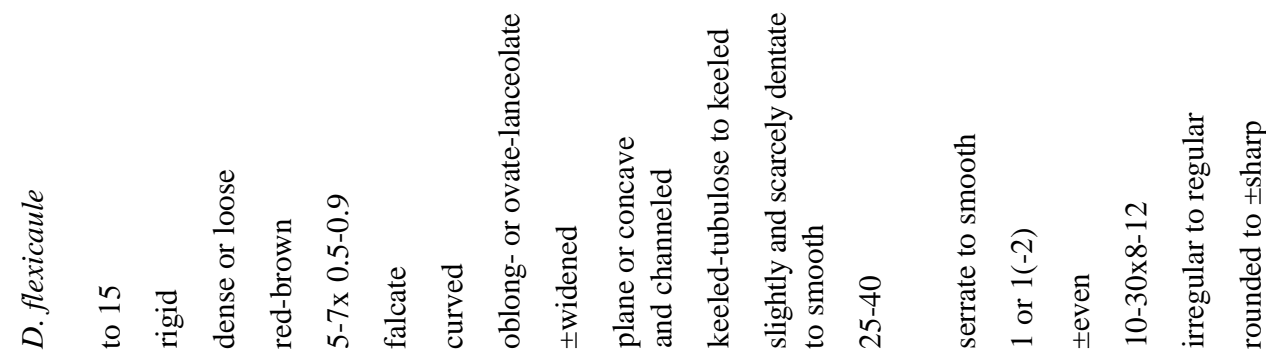

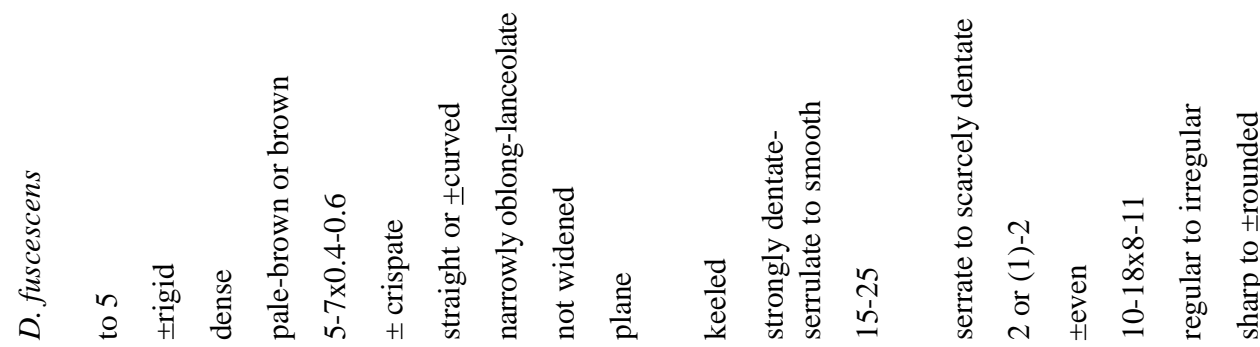

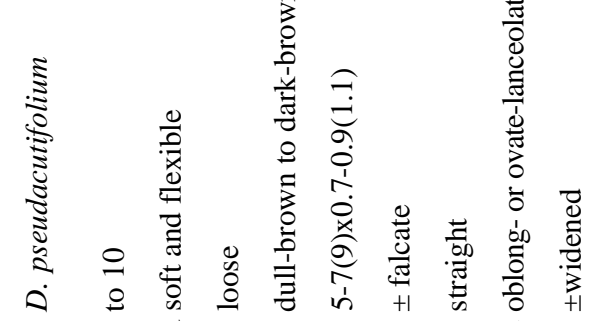

:<smiles>CC1CCCCC1C</smiles>

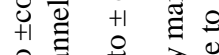

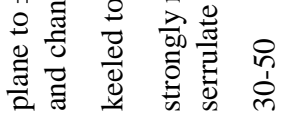

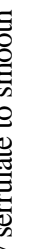

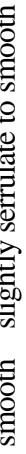
ㅇำ

흠

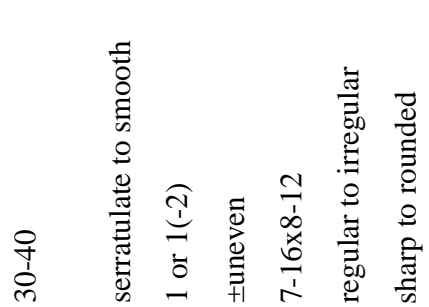

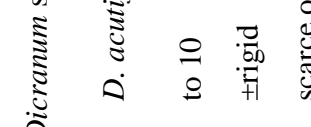

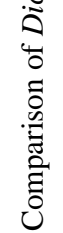

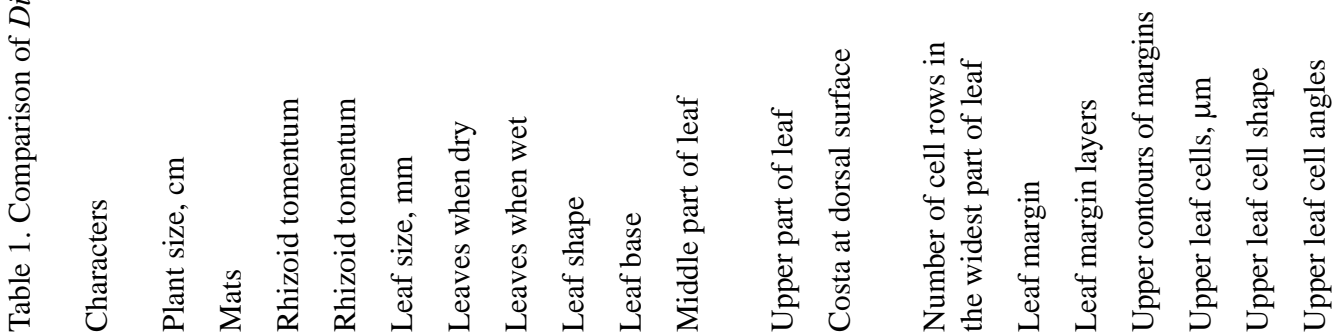

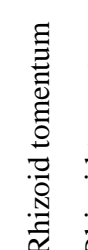

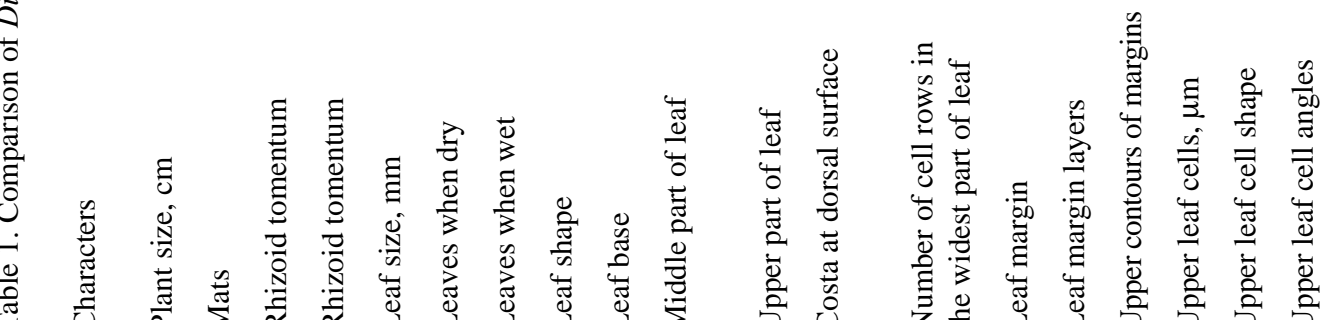

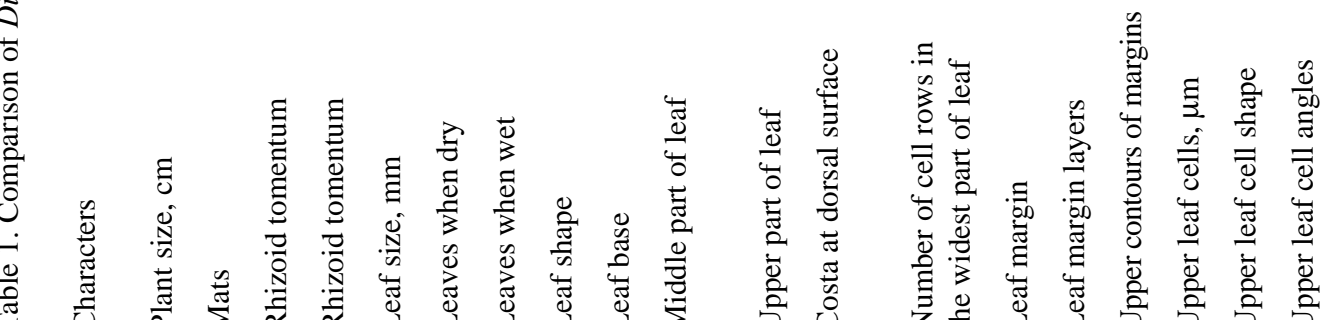

퓽

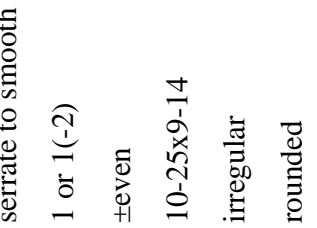




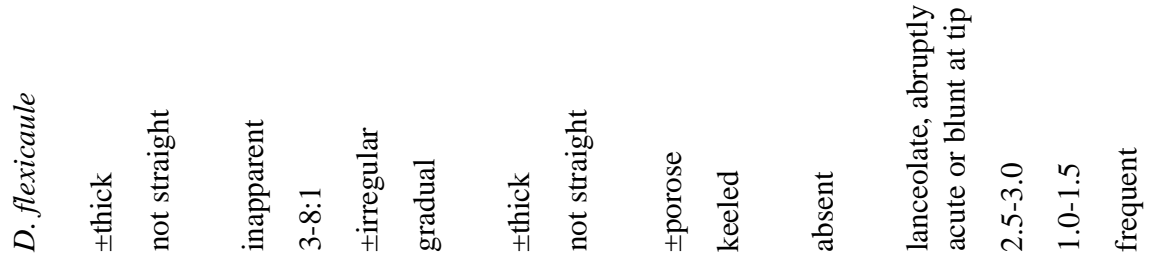

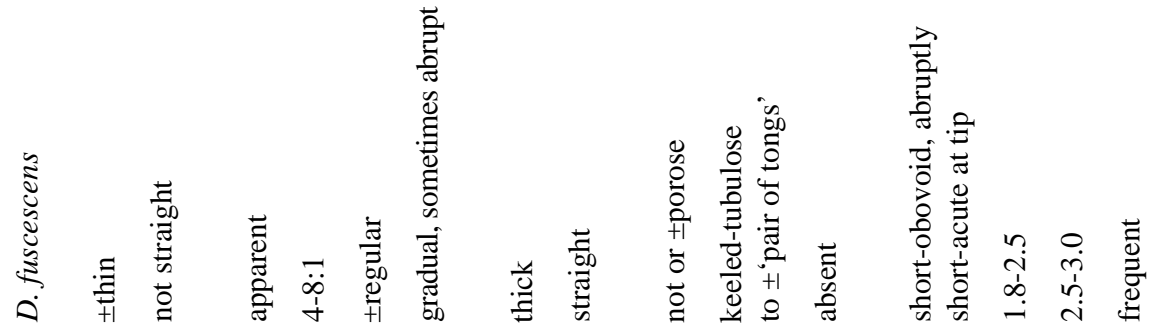

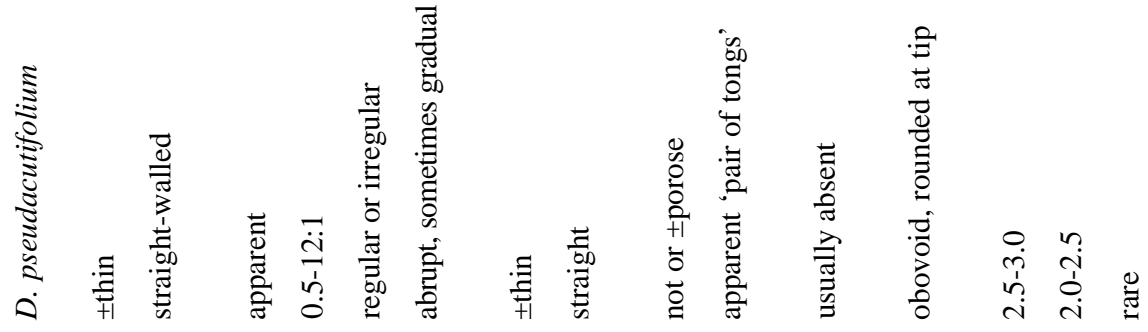

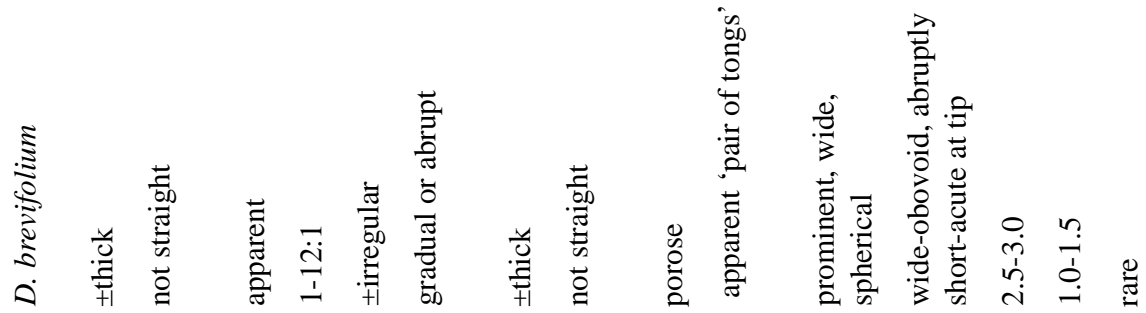

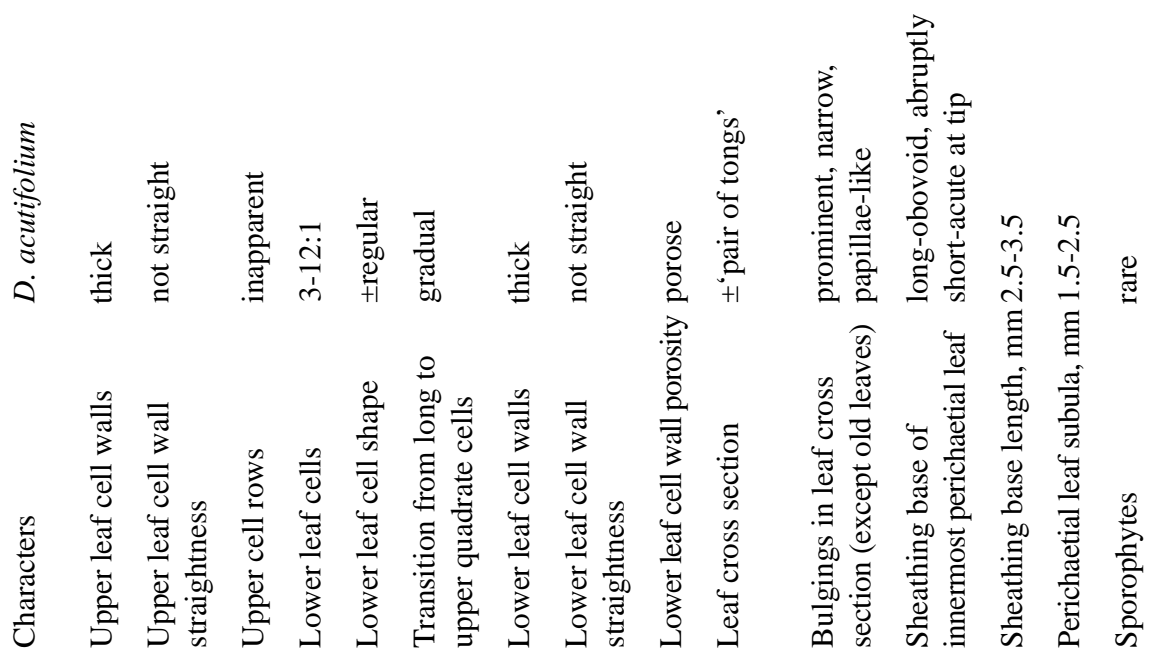


SPECIMENS EXAMINED: Krasnoyarsk Territory: Putorana Plateau: Lama Lake at mouth of Neralakh River, 200 m elev., open larch stand, on skeleton soil, 28.VII.1991; Glubokoye Lake, $150 \mathrm{~m}$ elev., larch forest, on soil, 6.VIII.1990; Gorbiachin River, 200 m elev., larch forest, on rocky soil, 20.VII.1991; Kulyumbe River, 200 $\mathrm{m}$ elev., spruce-larch forest, on rock among mosses, 25.VII.1991; Tonengda River (Severnaya River basin), spruce-larch forest, on decaying log, 17.VII. 1991. All collections made by T.N. Otnyukova, specimens in KRS.

\section{ACKNOWLEDGEMENTS}

I am very grateful to Dr N.V. Stepanov for correction of Latin diagnosis. The work was partly supported by RFBR, 05-04-48780. 